Vol.59: e16160330, January-December 2016 http://dx.doi.org/10.1590/1678-4324-2016160330 ISSN 1678-4324 Online Edition
BRAZILIAN ARCHIVES OF BIOLOGY AND TECHNOLOGY

AN INTERNATIONAL JOURNAL

\title{
Evaluation of Water Variables in No-Take Zone of Ustica Marine Protected Area (Southern Tyrrhenian Sea)
}

\author{
Marilena Sanfilippo ${ }^{1 *}$, Gioele Capillo ${ }^{1}$, Nunziacarla Spanò ${ }^{1}$, Antonio Manganaro ${ }^{1}$ \\ ${ }^{I}$ University of Messina - Department of chemical, biological, pharmaceutical and environmental sciences Messina, \\ ME, Italy.
}

\begin{abstract}
In this research, the seasonal fluctuations of the main water variables in the no-take area (A zone) of the Ustica MPA were investigated. This study aims to monitor the water quality of the Ustica MPA, to analyze all the hydrological parameters useful to the physical-chemical characterization of water and to use TRIX index to characterize the trophic level of the coastal marine area. The final results shown that Ustica is an area of relevant environmental and ecological value and is a good example of a Marine Protected Area, which is not excessively affected by the human presence even during the touristic season. This study represents the first records based on well-organized protocol in order to assess water column characteristics of the studied area. This paper could be used as a reference document for future studies regarding the same or similar areas.
\end{abstract}

Key words: Ustica Island; MPA; no-take zone; water quality; water variables.

\footnotetext{
*Author for correspondence: msanfilippo@unime.it
} 


\section{INTRODUCTION}

Marine Protected Area (MPA) is a commonly used tool for marine biodiversity protection (marine species, habitats and ecological processes) that represents an important approach to integrated management of marine resources that fully respects the fragile stability of some ecosystems (1-4)

The term MPA covers a wide range of different approaches for the management of coastal and marine areas. IUCN defines a protected area as "An area of land and/or sea especially dedicated to the protection of biological diversity, and of natural and associated cultural resources, and managed through legal or other effective means" (5); it is "Any area of intertidal or subtidal terrain, together with its overlying water and associated flora, fauna, historical and cultural features, which has been reserved by law or other effective means to protect part or all of the enclosed environment" (6).

The goal of Marine Protected Areas (MPAs) is to protect the biodiversity and productivity of a fragile environment, to restore and maintain ecosystem health. By protecting habitats, MPAs safeguard the vital life-support processes of the sea, including photosynthesis, maintenance of food chains, movement of nutrients, degradation of pollutants and conservation of biological diversity and productivity. The protection of marine habitats in their natural state provides an essential foundation for sustainable tourism, benefits to local communities and maintenance of natural water variables (7-10). Different benefits derive from MPAs, such as: conservation of biodiversity, especially critical habitats of threatened species; increased productivity of fisheries providing a buffer against recruitment failure, increase in densities and average sizes of individuals and the provision of centres for dispersal of propagules and adults (spillover); contain more natural species composition, age structure, spawning potential and genetic variability; refuge for intensely exploited species; protection of genetic diversity and protection of cultural diversity (6)

In the Mediterranean Sea there has been a rush in recent years to establish MPAs and reserves (7) and 677 MPAs have been identified (9). The zonation of all Mediterranean MPAs consists of two or three levels, with the distinction of a notake area (also called no-entry), where all human activities are generally prohibited, except for the mandatory interventions of managers and scientific research. The size of this protection zone is always relatively small (65-100 $h a$, comprising around $7-10 \%$ of the total reserve area). This zone is surrounded by a buffer area, where some activities are forbidden (e.g. spearfishing, scuba diving, amateur line fishing), or exposed to limitations and surveillance. Small-scale professional fishing is usually allowed in buffer zones, although restricted by bounds defined by MPA institutions. In some MPAs there is also a third peripheral zone (e.g. Ustica and Tabarca) with a less restricted regulation of activities (11). In Italy there are currently 29 MPAs formally founded, ranging in size from 120 to more than 50,000 hectares in total surface area. Italian MPAs are multiple-use protected areas conventionally implemented according to different protection levels (12) and include one or more no-take/noentry zones (hereafter formally defined as 'A zones' according to Italian law), surrounded by buffer zones (defined as 'B and C zones', where restrictions to human uses, including fishing, become progressively more lax) (13).

MPAs have very important roles in environmental preservation. The characteristics of a water body depend on various factors. Human activities could lead to many changes in water composition, in term of input of some compounds, representing a risk of environment "pollution". Excessive nutrient discharges can lead to accelerated eutrophication of coastal environments and adverse symptoms of over enrichment (14). On the other hand, chemical contaminants from urban and industrial activities can be potentially toxic for organisms living both within the sediments and the water column (15). Aquatic ecosystems are increasingly stressed not only by increased nutrient loads (eutrophication) but also by changing proportions of nutrients (16). Other stressors can be identified in changes of salinity, $\mathrm{pH}$ and dissolved oxygen. These variables are easily influenced by the human intervention with different activities. To preserve the aquatic environment, the natural balances of water variables should be maintained (17). An integral protection zone (no-take area) could avoid these processes. For this reason, the present research has been conducted to evaluate the seasonal fluctuations of the main water variables, also related to human influence, in the no-take area of Ustica MPA. This paper represents the first attempt to establish well organized protocols of 
water characteristics evaluations, following the directives of the Afrodite project (18) and reports the seasonal fluctuations of water variables, creating a starting point that might be proposed as guidelines for future research in the same or similar areas.

\section{MATERIAL AND METHODS}

\section{Study area}

"Isola di Ustica" MPA was founded in 1986 by the ministerial decree of 12/11/1986, and represents, with Miramare (Trieste), the first MPA in Italy. Situated in the southern Tyrrhenian Sea, about 36 miles northwest of Palermo (Sicily, Italy), it is also a Site of Community Interest (SCI), under the European Habitat Directive (92/43/EEC of 2.05.1992), for its environmental and biodiversity value. The MPA extends for $15 \mathrm{~km}$ around the island, covering $15.951 \mathrm{ha}$. The no-take area covers about $60 h a$ from Punta Spalmatore to Punta Megna (around $1.5 \mathrm{~km}$ of coast). The protection level of this zone allows for complete recovery of fish stocks and marine ecosystems, away from human impact. No human activity is allowed in this zone, including fishing, diving and boating, with the exception of swimming from the shore. A middle buffer area (B zone) extends around the latter, covering about 8000 ha in the northern part of the island from Punta Cavazzi to Punta Omo Morto. In this area, the MPA management authority regulates different activities, including fishing, boating and diving; a peripheral buffer area ( $\mathrm{C}$ zone) is located on the southern coast of the Island and covers about 8000 $h a$. In this zone, many activities are allowed, including professional and recreational fishing under the management of the MPA authority (1921).

\section{Sampling design}

This study was carried out seasonally during 2002, by sampling water from two different stations, St. 1 and St. 2 at various depths, in the A zone of the marine reserve of Ustica Island (Fig. 1).

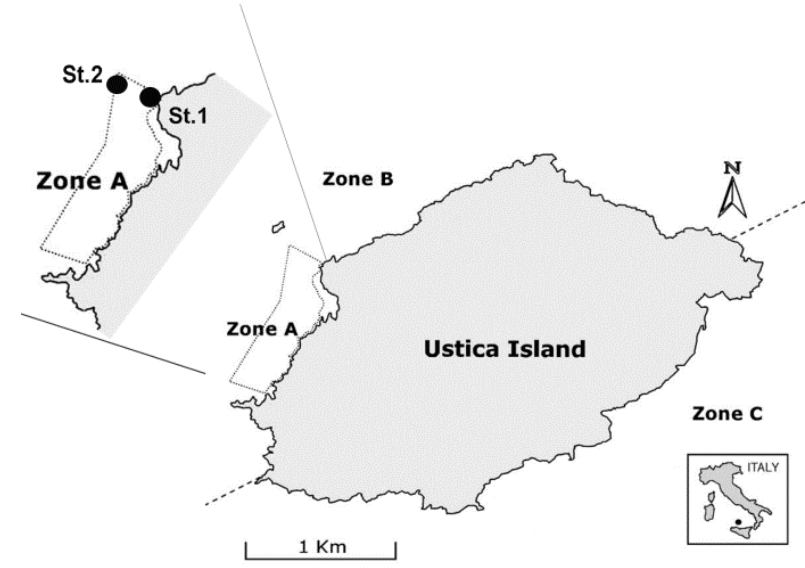

Figure 1 - Study area with sampling points and zonation of MPA.

The sampling points for each station were established after considering the seafloor morphology and according to the Italian National project "Sistema Afrodite":

- $\quad$ St. 1 (max depth: $10 \mathrm{~m}) \rightarrow$ two sampling depths (0-7 m);

- St. 2 (max depth: $45 \mathrm{~m}) \rightarrow$ four sampling depths (0-10-30-40 m).

The 'Sistema Afrodite' had four main objectives: to create a uniform knowledge base, to aid the creation of a national system of MPAs, to foster co-operation among scientists at national level and to set the foundations for a Mediterranean network of MPAs. This triennial programme (2001-2004) encompassed a number of coordinated activities, generally focused on the 'A' zones (no-take areas) of the instituted Italian MPAs and aiming to provide a template that would standardize research throughout the Mediterranean, thus catalysing the creation of unified operating networks integrated within a true system of Mediterranean MPAs (18).

\section{Analytical methods}

The water quality is dependent on geological, biological and climatological conditions. These conditions control composition, ion balances and biological cycles of the water body. Knowledge of the background quality is necessary to assess the suitability of water for use and to detect future human impacts. Determining the hydrological regime of a water body is an important aspect of a water quality assessment (17)

Temperature, Salinity, $\mathrm{pH}$ and Dissolved Oxygen, were measured along the water column, using a multi-parametric probe IM201 (Idromar s.r.l., Milano, Italy). The Winkler method was used for the determination of DO in order to calibrate the 
oxygen sensor (22). Water samples were collected to analyse salt nutrients, total suspended matter (TSM) and colimetric indices, using a Niskin bottle. For dissolved and total nutrients and TSM determinations, the water samples were filtered onto pre-washed, pre-combusted $\left(450^{\circ} \mathrm{C}, 4 \mathrm{~h}\right)$ and pre-weighed $47 \mathrm{~mm}$ Whatman $\mathrm{GF} / \mathrm{F}$ filters $(0.45 \mu \mathrm{m}$ nominal pore size). Filters were analysed by gravimetric method so to establish the total TSM $\left(\mathrm{mgL}^{-1}\right)$, its inorganic (ISM, $\mathrm{mgL}^{-1}$ ) and organic fractions (OSM, $\mathrm{mg} \mathrm{L}^{-1}$ ). Spectrophotometric methods (Varian Cary50 Probe spectrophotometer, Varian, ink. Palo Alto, CA, USA) were used for the determination of inorganic nutrients $\left(\mathrm{N}^{-\mathrm{NO}_{2}}, \mathrm{~N}-\mathrm{NO}_{3}, \mathrm{~N}-\mathrm{NH}_{4}, \mathrm{P}-\right.$ $\mathrm{PO}_{3}, \mathrm{Si}-\mathrm{SiO}_{2}$ ), total nitrogen (TN) and total phosphorous (TP), according to Standard Methods (22). All analyses were carried out in three replicates.

Microbiological pollution indices (Total coliforms-TC, Faecal Coliforms-FC, Faecal Streptococci-FS) were determined according to Italian Presidential Decree 470/82.

A trophic index (TRIX) was also used to establish succinctly the trophic levels of the coastal marine area $(23,24)$.

TRIX Index formulation is the following:

$T R I X=(\log [C h A \times a D \% O \times \min N \times T P]+k) /$ $m$

Each of the four components represents a trophic state variable, namely:

a) factors that are direct expression of productivity:

ChA = chlorophyll-a concentration, as $\mu \mathrm{g} l^{-1}$; $a D \% O=$ Oxygen as absolute \% deviation from saturation $=[a b s|100 \pm \% 0|]$;

b) nutritional factors:

minN = mineral nitrogen: dissolved inorganic nitrogen, $\mathrm{DIN}=\mathrm{N}\left(\right.$ as $\left.\mathrm{N}-\mathrm{NO}_{3}+\mathrm{N}-\mathrm{NO}_{2}+\mathrm{N}-\mathrm{NH}_{4}\right)$, as $\mu g l^{-1}$;

$T P=$ total phosphorus, as $\mu \mathrm{g} l^{-1}$.

The parameters $k=1.5$ and $m=12 / 10=1.2$, are scale coefficients, introduced to fix the lower limit value of the Index and the extension of the related Trophic Scale, from 0 to 10 TRIX units (23). Statistical analyses were carried out to determine the various degrees of correlations between different parameters, sampling points and seasons. Box and whiskers diagrams were utilized to evaluate significant differences among seasons for all salt nutrients. The statistical Spearman correlation coefficient, or rho, was used to evaluate the degree of relationship between all the analysed variables, as a measure of the strength of correlation. Spearman's rho is a non-parametric test used to measure the strength of association between two variables, where the value $r=1$ means a perfect positive correlation and the value $r$ $=-1$ means a perfect negative correlation.

\section{RESULTS AND DISCUSSIONS}

Seasonal mean values and standard deviations of all water characteristics, in the two stations, are reported in tables 1 (A-B). Spearman rank order correlations among all analysed parameters are reported in table 2 .

Table 1A - Mean value \pm standard deviation St. 1

\begin{tabular}{|c|c|c|c|c|c|}
\hline & $\mathrm{T}\left({ }^{\circ} \mathrm{C}\right)$ & Sal (PSU) & $\mathrm{pH}$ & $\mathrm{DO}(\%)$ & CHL-a $(\mu \mathrm{g} / \mathrm{l})$ \\
\hline Winter & $15.85 \pm 0.24$ & $37.60 \pm 0.07$ & $8.29 \pm 0.01$ & $103.60 \pm 0.42$ & $1.92 \pm 0.09$ \\
\hline Spring & $26.76 \pm 1.2$ & $37.30 \pm 0.01$ & $8.35 \pm 0.02$ & $126.11 \pm 0.86$ & $0.40 \pm 0.01$ \\
\hline Summer & $26.25 \pm 0.17$ & $37.96 \pm 0.01$ & $8.31 \pm 0.02$ & $120.01 \pm 1.97$ & $0.39 \pm 0.05$ \\
\hline Autumn & $18.80 \pm 0.07$ & $38.01 \pm 0.01$ & $8.53 \pm 0.02$ & $101.39 \pm 0.08$ & $0.28 \pm 0.01$ \\
\hline \multirow{2}{*}{ Yearly } & $21.91 \pm 4.82$ & $37.79 \pm 0.21$ & $8.37 \pm 0.10$ & $112.78 \pm 10.76$ & $0.75 \pm 0.69$ \\
\hline & $\mathrm{N}-\mathrm{NH}_{4}(\mu \mathrm{M})$ & $\mathrm{N}-\mathrm{NO}_{2}(\mu \mathrm{M})$ & $\mathrm{N}-\mathrm{NO}_{3}(\mu \mathrm{M})$ & $\mathrm{P}^{-\mathrm{PO}_{4}(\mu \mathrm{M})}$ & $\mathrm{Si}_{-} \mathrm{SiO}_{2}(\mu \mathrm{M})$ \\
\hline Winter & $1.24 \pm 0.10$ & $0.12 \pm 0.11$ & $3.00 \pm 3.29$ & $0.31 \pm 0.06$ & $15.56 \pm 12.50$ \\
\hline Spring & $1.47 \pm 0.11$ & $0.15 \pm 0.19$ & $0.34 \pm 0.21$ & $0.15 \pm 0.08$ & $10.36 \pm 4.19$ \\
\hline Summer & $4.28 \pm 0.09$ & $0.04 \pm 0.01$ & $0.95 \pm 0.42$ & $0.24 \pm 0.07$ & $2.38 \pm 0.26$ \\
\hline Autumn & $4.38 \pm 0.60$ & $0.04 \pm 0.03$ & $0.80 \pm 0.12$ & $0.09 \pm 0.04$ & $2.48 \pm 0.33$ \\
\hline Yearly & $2.84 \pm 1.61$ & $0.09 \pm 0.10$ & $1.27 \pm 1.67$ & $0.20 \pm 0.10$ & $7.70 \pm 7.77$ \\
\hline
\end{tabular}


Evaluation of Water Variables in Ustica MPA

Table 1B - Mean value \pm standard deviation St. 2

\begin{tabular}{|c|c|c|c|c|c|}
\hline & $\mathrm{T}\left({ }^{\circ} \mathrm{C}\right)$ & Sal (PSU) & $\mathrm{pH}$ & $\mathrm{DO}(\%)$ & CHL-a $(\mu \mathrm{g} / \mathrm{l})$ \\
\hline Winter & $15.28 \pm 0.26$ & $37.30 \pm 0.13$ & $8.28 \pm 0.01$ & $99.09 \pm 0.93$ & $2.90 \pm 0.75$ \\
\hline Spring & $22.64 \pm 2.54$ & $37.69 \pm 0.10$ & $8.41 \pm 0.02$ & $124.53 \pm 1.93$ & $0.35 \pm 0.04$ \\
\hline Summer & $24.11 \pm 1.98$ & $37.94 \pm 0.05$ & $8.20 \pm 0.02$ & $120.12 \pm 1.53$ & $0.49 \pm 0.14$ \\
\hline Autumn & $18.76 \pm 0.06$ & $37.97 \pm 0.03$ & $8.56 \pm 0.01$ & $98.64 \pm 0.18$ & $0.38 \pm 0.06$ \\
\hline \multirow[t]{2}{*}{ Yearly } & $20.20 \pm 3.81$ & $37.73 \pm 0.28$ & $8.36 \pm 0.14$ & $110.60 \pm 11.94$ & $1.03 \pm 1.15$ \\
\hline & $\mathrm{N}-\mathrm{NH}_{4}(\mu \mathrm{M})$ & $\mathrm{N}-\mathrm{NO}_{2}(\mu \mathrm{M})$ & $\mathrm{N}-\mathrm{NO}_{3}(\mu \mathrm{M})$ & $\mathrm{P}^{-\mathrm{PO}_{4}(\mu \mathrm{M})}$ & $\mathrm{Si}_{-} \mathrm{SiO}_{2}(\mu \mathrm{M})$ \\
\hline Winter & $0.99 \pm 0.28$ & $0.18 \pm 0.13$ & $3.35 \pm 3.00$ & $0.41 \pm 0.16$ & $17.72 \pm 12.61$ \\
\hline Spring & $1.61 \pm 0.57$ & $0.04 \pm 0.02$ & $0.18 \pm 0.06$ & $0.10 \pm 0.02$ & $6.78 \pm 1.00$ \\
\hline Summer & $3.77 \pm 0.39$ & $0.07 \pm 0.02$ & $2.73 \pm 1.40$ & $0.26 \pm 0.15$ & $7.83 \pm 4.72$ \\
\hline Autumn & $3.88 \pm 0.32$ & $0.06 \pm 0.02$ & $0.91 \pm 0.33$ & $0.15 \pm 0.07$ & $6.83 \pm 7.73$ \\
\hline Yearly & $2.56 \pm 1.37$ & $0.09 \pm 0.08$ & $1.80 \pm 2.00$ & $0.23 \pm 0.16$ & $9.79 \pm 8.40$ \\
\hline
\end{tabular}

Table 2 - Spearman rank order correlation among all variables observed

\begin{tabular}{|c|c|c|c|c|c|c|c|c|c|c|}
\hline & $\mathrm{T}$ & SAL & $\mathrm{pH}$ & DO & CHL-a & $\mathrm{N}-\mathrm{NH}_{4}$ & $\mathrm{~N}-\mathrm{NO}_{2}$ & $\mathrm{~N}-\mathrm{NO}_{3}$ & $\mathrm{P}-\mathrm{PO}_{4}$ & $\mathrm{Si}-\mathrm{SiO}_{2}$ \\
\hline $\mathrm{T}$ & 1 & $0.346^{* * *}$ & $-0.162 *$ & 0.746 *** & $-0.503 * * *$ & $0.441^{*}$ & -0.389 & -0.359 & -0.329 & -0.214 \\
\hline SAL & & 1 & $0.337 * * *$ & -0.124 & $-0.545 * * *$ & $0.785^{* * *}$ & -0.254 & -0.01 & -0.311 & $-0.589 * *$ \\
\hline $\mathrm{pH}$ & & & 1 & $-0.263 * * *$ & -0.547 & 0.219 & -0.377 & $-0.442 *$ & $-0.600 * *$ & -0.341 \\
\hline DO & & & & 1 & $-0.345 * * *$ & 0.029 & -0.330 & $-0.476^{*}$ & -0.327 & 0.001 \\
\hline Chl-a & & & & & 1 & $-0590 * *$ & $0.447 *$ & 0.366 & $0.541^{* *}$ & $0.574 * *$ \\
\hline $\mathrm{N}-\mathrm{NH}_{4}$ & & & & & & 1 & -0.229 & 0.236 & -0.254 & $-0.508 *$ \\
\hline $\mathrm{N}-\mathrm{NO}_{2}$ & & & & & & & 1 & $0.602 * *$ & $0.523^{* *}$ & $0.542 * *$ \\
\hline $\mathrm{N}-\mathrm{NO}_{3}$ & & & & & & & & 1 & $0.565^{* *}$ & 0.268 \\
\hline $\mathrm{P}-\mathrm{PO}_{4}$ & & & & & & & & & 1 & $0.544 * *$ \\
\hline $\mathrm{Si}-\mathrm{SiO}_{2}$ & & & & & & & & & & 1 \\
\hline
\end{tabular}

$* \mathrm{P}<0.05, * * \mathrm{P}<0.01, * * * \mathrm{P}<0.001$

Vertical profiles of temperature (T), salinity (S), $\mathrm{pH}$ and dissolved oxygen (DO) in the different seasons and stations are reported as graphs (Fig. 2 and 3), considering the variations among the different depths. All over the sampling period, results show similar trends between the two stations for these parameters. The evaluation of these characteristics leads to different observations and the particular pattern could be explained as follow.

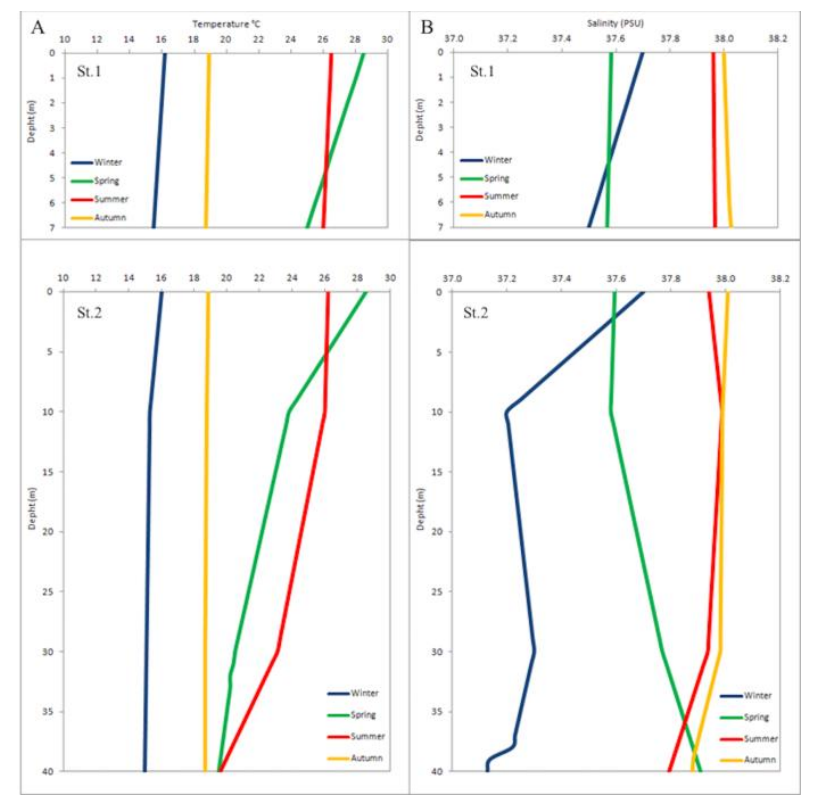

Figure 2 - Vertical profiles of parameters measured by multiparametric probe; A: Temperature $\left({ }^{\circ} \mathrm{C}\right)$; B: Salinity (PSU). 


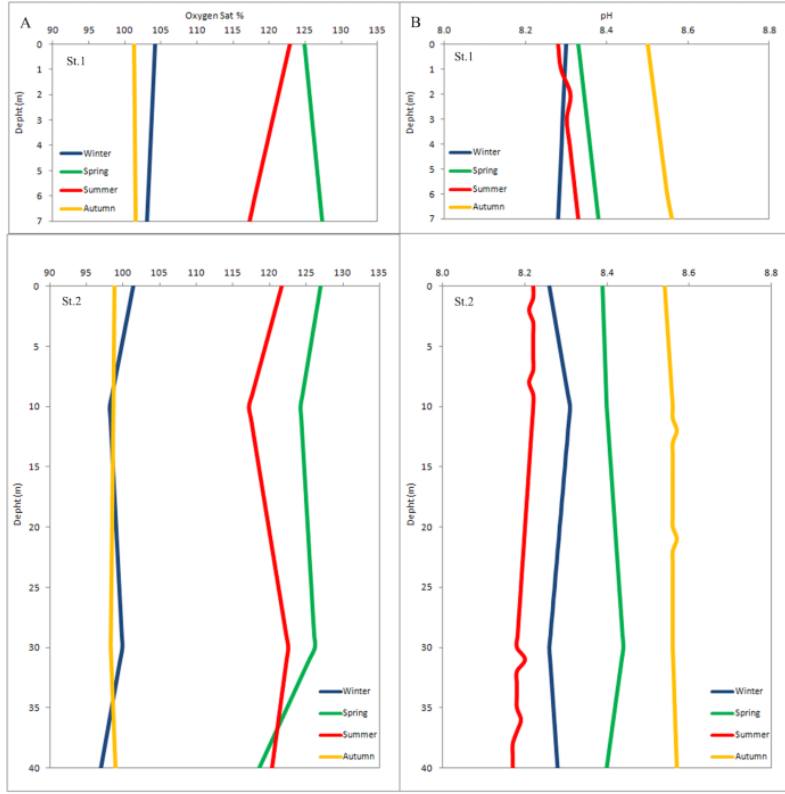

Figure 3 - Vertical profiles of parameters measured by multiparametric probe; A: Dissolved Oxygen (Sat\%); B: $\mathrm{pH}$.

The temperature of surface waters is influenced by latitude, altitude, season, time of day, air circulation, cloud cover, flow and depth of the water body. In turn, temperature affects physical, chemical and biological processes in water bodies and, therefore, the concentration of many variables. The temperature profiles (Fig. 2A), do not show, during summer, a well established thermocline. The temperature fluctuates between 15.0 and $28.5^{\circ} \mathrm{C}$. The same particular tendency is noticeable in the salinity trend (Fig. 2B), except during the winter season. All over the year, the salinity range was between 37.1 and 38.0 PSU. The reason of this particular pattern of $T$ and $S$ values could be related to the general characteristics of Ustica Island, due to its geographical position. In fact, it is located on the pathway of a minor branch of the Atlantic Water in the centre of Mediterranean circulation, and the variability of its hydrologic parameters is sensitive to the transit of eddies along the edge of the Atlantic current along the northern coast of Sicily $(21,25,26)$.

Spearman rank order (Tab. 2) shows significant positive correlations $(\mathrm{P}<0.001)$ between $\mathrm{T}, \mathrm{S}$ and $\mathrm{DO}$, while negative ones with $\mathrm{pH}(\mathrm{P}<0.05)$. $\mathrm{T}$ seems to influences negatively the Chl-a $(\mathrm{P}<0.001)$ however, it is positively related only with ammonia $(\mathrm{P}<0.05)$. Salinity has a significant positive correlation $(\mathrm{P}<0.001)$ with $\mathrm{pH}$ and ammonia and a negative one with silicate.
The $\mathrm{pH}$ is an important variable in water quality assessment as it influences many biological and chemical processes within a water body and all processes associated with water supply and treatment. The $\mathrm{pH}$ of most natural waters is between 6.0 and 8.5, although lower values can occur in dilute waters high in organic content, and higher values in eutrophic waters. Variations in $\mathrm{pH}$ can be caused by the photosynthesis and respiration cycles of algae in eutrophic waters (17). pH (Fig. 3B) shows typical seasonal trend, ranging from 8.17 in summer to 8.57 in autumn. Minor fluctuations of the $\mathrm{pH}$ values, also during the touristic periods, highlight the stability of the water body. It is negatively related to DO $(\mathrm{P}<0.001)$, to nitrite $(\mathrm{P}<0.05)$ and to phosphate $(\mathrm{P}<0.01)$.

Determination of DO is fundamental in water quality assessment. Oxygen is involved in, or influences, chemical and biological processes. Variations in DO can occur seasonally, in relation to temperature and biological activity (photosynthesis and respiration). DO profiles (Fig. 3A) show a typical seasonal pattern, with values close to saturation in winter and autumn (97-98\%) and super saturation in spring (127\%) and summer (123\%), showing homogeneity of values along the water column (27). Oxygen super saturation (values $>120 \%$ ), can indicate elevated phytoplankton photosynthesis and this is confirmed by the abundant presence of PK (data not showed) observed during this seasons $(28,29)$. DO shows a significant negative correlation with $\mathrm{pH}(\mathrm{P}<0.001)$, that should be in part confirmed by Frieder et al (2012) (30), in case of high values of DO, and also with Chl-a $(\mathrm{P}<0.001)$, as also reported by Kunlasak et al (2013) (31).

Concentrations of salt nutrients and Chl- $a$ are summarized in Tables $1 \mathrm{~A}$ and $\mathrm{B}$ and reported as graph in Figure 4, with median, 25\% and $75 \%$ percentile, maximum and minimum highlighted. The concentrations of inorganic nutrients and chlorophyll-a show different trends related to different seasons. The nutritive salts are all positively correlated with each other $(\mathrm{P}<0.01)$, except the ammonia, which does not show correlations with any salts, except a low negative correlation with the silicates $(\mathrm{P}<0.05)$. Ammonia reaches its maximum values in summer and autumn, ranging from 3.30 to $4.80 \mu \mathrm{M}$. The lowest concentrations are in winter with a minimum of $0.69 \mu \mathrm{M}$ (Fig. 4A). Nitrite and nitrate (Fig. 4B and 4C) show similar seasonal trends, with higher 
values in winter $\left(\mathrm{NO}_{2}: 0.31 \mu \mathrm{M} ; \mathrm{NO}_{3}: 6.57 \mu \mathrm{M}\right.$, with an outlier value of $4.56 \mu \mathrm{M}$ in summer). Phosphates (Fig. 4D) have low values during all the year, with slightly higher values during winter (median of $0.4 \mu \mathrm{M}$, with an outlier value of 0.47 $\mu \mathrm{M})$. Silicates are the nutritive salts that show very high values, with a wide range $(2.13-30.34 \mu \mathrm{M})$, and reach the maximum value in winter, with a median of $15.92 \mu \mathrm{M}$. There is an outlier value of 18.23 in autumn (Fig. 4E). Although the salt nutrients are connected to each other, particular attention should be given to the significantly positive correlation between the silicate and chlorophyll $(\mathrm{P}<0.01)$. This correlation is due to the massive presence of diatoms in winter (data not published) causing an increase in the value of silicate during the same season (32).
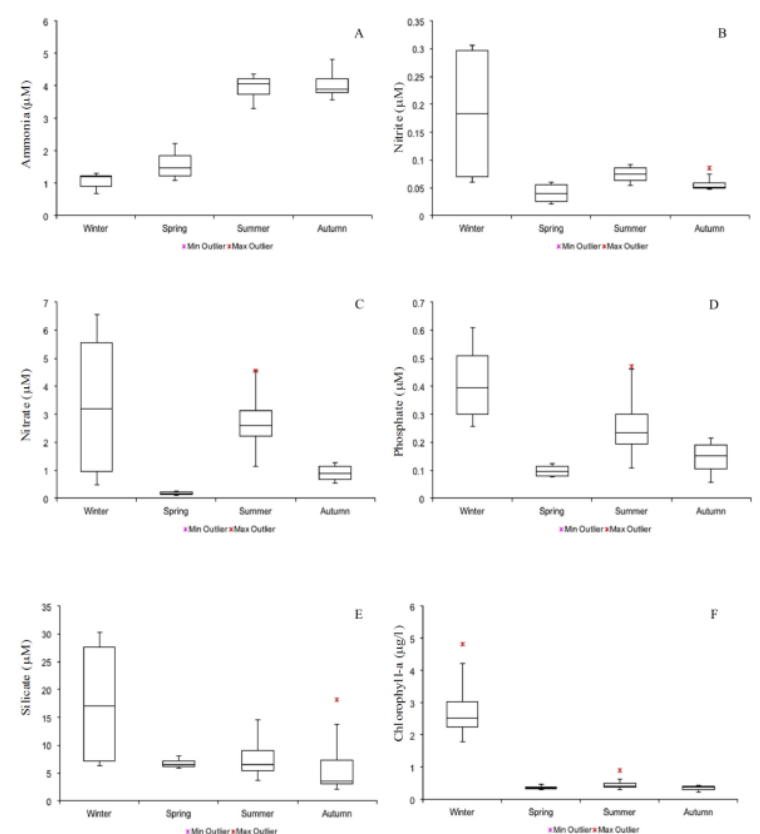

Figure 4 - Median, percentile $25 \%$ and $75 \%$, maximum, minimum and outliers of Ammonia (A), Nitrite (B), Nitrate (C), Phosphate (D), Silicate (E) and
Chlorophyll-a (F) in the examined area, during the different seasons.

Chl-a was significantly related to ammonium $(\mathrm{P}<0.01)$, and the parameter estimated was negative, indicating a relationship of higher biomass and lower $\mathrm{NH}_{4}{ }^{+}$concentrations; there is a positive correlation with nitrite $(\mathrm{P}<0.05)$, phosphate $(\mathrm{P}<0.01)$ and silicate $(\mathrm{P}<0.01)$. Similar values of rho were found in others studies on coastal waters $(33,34)$. Chl- $a$ reaches its highest values during winter (maximum of $4.81 \mu \mathrm{g} / \mathrm{l}$, median of $2.71 \mu \mathrm{g} / \mathrm{l})$ whereas the lowest concentration occurs in autumn $(0.22 \mu \mathrm{g} / \mathrm{l})$ with a median of $0.35 \mu \mathrm{g} / \mathrm{l}$ (Fig. 4F).

The results of the analysis on the microbiological indices in the two examined stations indicate that there is no influence due to a population increase in the summer, on the quality of water; in fact, none of indices exceed the limit for bathing in Italy (100 FCU/100ml) even though the highest values are far from reaching the limits. The maximum of $\mathrm{FC}$ is of $28 \mathrm{CFU} / 100 \mathrm{ml}$ during autumn, compared to that of $24 \mathrm{CFU} / 100 \mathrm{ml}$ of TC during the summer.

TRIX (Trophical index for marine ecosystems) was used to assign an immediate measurement to the trophic level of coastal waters. It is a tool adopted by Italian legislation in the frame of the monitoring activities requested to assess quality of Italian coastal marine environment (L.D. 152/99 Annex 1, Tab. 3). It is defined by a linear combination of the logarithms of four state variables: chlorophyll- $a$ (ChA), Oxygen as absolute percent deviation from saturation $(\mathrm{aD} \% \mathrm{O})$, mineral nitrogen $(\mathrm{minN})$ and total phosphorus (TP).

Table 3 - TRIX Index and water quality

\begin{tabular}{lll}
\hline Trophic scale & State & Conditions \\
\hline $2-4$ & High & $\begin{array}{l}\text { Water poorly productive } \\
\text { Low trophic level }\end{array}$ \\
& & Water moderately productive \\
$4-5$ & Good & Mean trophic level \\
& & Water moderate to highly productive \\
$5-6$ & Mediocre & High trophic level \\
& & Water highly productive \\
$6-8$ & Poor & Greatest trophic level \\
\hline
\end{tabular}

According to this rating scale $(35,36)$ and to

the Italian seas, values exceeding 6 TRIX units are Giovanardi e Vollenweider (2004) (23), regarding typical of highly productive coastal waters, where 
the effects of Eutrophication determine frequent episodes of anoxia in bottom waters. Values lower than 4 TRIX units are instead associated to scarcely productive coastal waters, while values lower than 3 are usually found in the open sea.

In Ustica MPA, TRIX values (Tab. 4) showed that the trophic status of this reserve can be considered moderately productive waters with good transparency and average trophic level in winter, spring and summer, having a "Good" value; whereas in autumn the conditions are of poorly productive waters and low trophic level, reporting "High" results.

Table 4 - TRIX index in Ustica MPA

\begin{tabular}{lllll}
\hline & Winter & Spring & Summer & Autumn \\
\hline St.1 & 4.5 & 4.5 & 5.0 & 3.7 \\
St.2 & 4.2 & 4.7 & 5.0 & 3.4 \\
Mean & 4.5 & 4.6 & 5.0 & 2.8 \\
\hline
\end{tabular}

\section{CONCLUSIONS}

The MPA of Ustica is an area of relevant environmental and ecological value and is a good example of Marine Protected Area that is not excessively affected by human presence, even during the tourist seasons. This is possible thanks to many factors, such as its geographic position, that allow good water circulation, high stability of no-take area ecosystem and restriction imposed by the MPA management authority. The results on the characteristics of water column of no-take zone of the Ustica MPA presented in this study show an excellent chemical and physical quality of water; whit regard to the microbiological indices, the data collected highlight low levels of contamination, that confirm that Ustica integral reserve water is a good example of environmental preservation. TRIX index, used to characterizing succinctly the trophic levels of the coastal marine area, shows that Ustica MPA has moderately productive waters with good transparency and average trophic level, highlighting even in autumn, similar characteristics to the open sea. Our research can be considered as a sort of integration of the knowledge of this MPA; in fact, several studies and observation have been conducted on flora, fauna and other topics, principally on the coastal fish and molluscan assemblage (37-42), but no data have been published on water variables. Water column analyses represent an essential topic in the evaluation of all water environments. This study reports for the first time important data on the water column characteristics of Ustica MPA and could represent a reference document for further environmental monitoring in this or similar areas.

\section{ACKNOWLEDGEMENTS}

The authors are grateful to Mr. Giovanni Maio and Dr. Giusy Cortese for help in the sampling and analysis as well as to Dr. Xenia Lo Giudice and to Dr. Adrian Grima for the critical review of the English text. Research supported by CoNISMa (Rome, Italy).

\section{REFERENCES}

1. Jones PJS. A review and analysis of the objectives of marine nature reserves. Ocean Coast Manag [Internet]. 1994 Jan [cited 2016 Feb 1];24(3):149-78. Available from: http://www.sciencedirect.com/science/article/pii/0964 569194900361

2. Agardy TM. Advances in marine conservation: the role of marine protected areas. Trends Ecol Evol [Internet]. 1994 Jul [cited 2016 Jan 10];9(7):267-70. Available from: http://www.sciencedirect.com/science/article/pii/0169 534794902976

3. Pomeroy RS, Watson LM, Parks JE, Cid GA. How is your MPA doing? A methodology for evaluating the management effectiveness of marine protected areas. Ocean Coast Manag [Internet]. 2005 Jan [cited 2016 Jan 26];48(7-8):485-502. Available from:

http://www.sciencedirect.com/science/article/pii/S096 4569105000955

4. Olsen EM. Achieving Ecologically Coherent MPA Networks in Europe: Science Needs and Priorities. Eur Mar Board Work Gr Mar Prot. 2013; (April):88.

5. IUCN. Guidelines for Protected Area Management Categories. IUCN, Cambridge, UK and Gland, Switzerland.; 1994.

6. Kelleher $\mathrm{G}$ (Ed). Guidelines for marine protected areas [Internet]. Best Practice Protected Area Guidelines Series. 1999. xxiv, 107p. : ill., maps. Available from: http://www.iucn.org/dbtwwpd/edocs/PAG-003.pdf

7. Juanes F. Mediterranean marine protected areas. Trends Ecol Evol [Internet]. 2001;16(4):16970. Available from: //000168454100003

8. Claudet J, Osenberg CW, Benedetti-Cecchi L, Domenici P, Garcìa-Charton JA, Pérez-Ruzafa A, et al. Marine reserves: Size and age do matter. Ecol Lett. 2008;11(5):481-9. 
9. Gabrié C, Lagabrielle E, Bissery C, Crochelet E, Meola B, Webster C, Claudet J, Chassanite A, Marinesque S, Robert P GM. The Status of Marine Protected Areas in the Mediterranean Sea. 2012. MedPAN \& RAC/SPA. Ed: MedPAN Collection, 256 p.

10. Gomei M, Di Carlo G, Making Marine Protected Areas Work. Lessons Learned in the Mediterranean. WWF Mediterranean, 2012, 56 p.

11. Francour P, Harmelin JG, Pollard D, Sartoretto S. A review of marine protected areas in the northwestern Mediterranean region: Siting, usage, zonation and management. Aquat Conserv Mar Freshw Ecosyst. 2001;11(3):155-88.

12. Tunesi L, Diviacco G. Environmental and socio- economic criteria for the establishment of marine coastal parks. Int J Environ Stud. 1993; 43:253-259.

13. Villa F, Tunesi L, Agardy T. Zoning marine protected areas through spatial multiple-criteria analysis: The case study of the Asinara Island National Marine Reserve of Italy. Conserv Biol. 2002;16(2):515-26.

14. Ferreira JG, Andersen JH, Borja A, Bricker SB, Camp J, Cardoso da Silva M, et al. Overview of eutrophication indicators to assess environmental status within the European Marine Strategy Framework Directive. Estuar Coast Shelf Sci [Internet]. Elsevier Ltd; 2011;93(2):117-31. Available from: http://dx.doi.org/10.1016/j.ecss.2011.03.014

15. Dafforn KA, Simpson SL, Kelaher BP, Clark GF, Komyakova V, Wong CKC, et al. The challenge of choosing environmental indicators of anthropogenic impacts in estuaries. Environ Pollut [Internet]. Elsevier Ltd; 2012;163:207-17. Available from: http://dx.doi.org/10.1016/j.envpol.2011.12.029

16. Simboura N, Pavlidou A, Bald J, Tsapakis M, Pagou K, Zeri C, et al. Response of ecological indices to nutrient and chemical contaminant stress factors in Eastern Mediterranean coastal waters. Ecol Indic [Internet]. Elsevier Ltd; 2016;70:89-105. Available from:

http://linkinghub.elsevier.com/retrieve/pii/S1470160 X16302539

17. Chapman D. Water Quality Assessments - A guide to use of biota, sediments and water in enviromental monitoring. Univ Press Cambridge ISBN [Internet]. 1996;2(1):609. Available from: http://www.who.int/water_sanitation_health/resource squality/watqualassess.pdf

18. Greco S, Di Sciara GN, Tunesi L. "Sistema Afrodite": An integrated programme for the inventorying and monitoring of the core zones of the Italian marine protected areas. Aquat Conserv Mar Freshw Ecosyst. 2004;14(SUPPL. 1):119-22.

19. Gianguzza P, Chiantore M, Bonaviri C, Cattaneo-Vietti R, Vielmini I, Riggio S. The effects of recreational Paracentrotus lividus fishing on distribution patterns of sea urchins at Ustica Island MPA (Western Mediterranean, Italy). Fish Res [Internet]. 2006 Oct [cited 2016 Feb 1];81(1):37-44. Available from: http://www.sciencedirect.com/science/article/pii/S016 5783606002232

20. Milazzo M, Badalamenti F, Ceccherelli G, Chemello R. Boat anchoring on Posidonia oceanica beds in a marine protected area (Italy, western Mediterranean): effect of anchor types in different anchoring stages. J Exp Mar Bio Ecol [Internet]. 2004 Feb [cited 2016 Feb 1];299(1):51-62. Available from:

http://www.sciencedirect.com/science/article/pii/S002 2098103004428

21. Sanfilippo M, Pulicanò G, Manganaro A, Reale A, Cortese G. Tyrrhenian Upper Waters in the Ustica Island (Marine Protected Area, Sicily, Italy). Int J Ecol. 2009; Article ID 161609, 7 p, 2009. doi:10.1155/2009/161609.

22. Eaton, A. D., Clesceri, L. S., Greenberg, A. E., Franson MAH. Standard Methods for the Examination of Water and Wastewater. American Public Health Association, editor. American Water Works Association., \& Water Environment Federation. Washington, DC; 1999. 541 p.

23. Giovanardi F, Vollenweider RA. Trophic conditions of marine coastal waters: Experience in applying the Trophic Index TRIX to two areas of the Adriatic and Tyrrhenian seas. $J$ Limnol. 2004;63(2):199-218.

24. Vollenweider RA, Giovanardi F, Montanari G, Rinaldi A. Characterization of the Trophic Conditions of Marine Coastal Waters With Special Reference To the Nw Adriatic Sea: Proposal for a Trophic Scale, Turbidity and Generalized Water Quality Index. Environmetrics;1998; 9:329-57.

25. Astraldi M, Gasparini GP, Vetrano A, Vignudelli S. Hydrographic characteristics and interannual variability of water masses in the central Mediterranean: A sensitivity test for long-term changes in the Mediterranean Sea. Deep Res Part I Oceanogr Res Pap. 2002;49(4):661-80.

26. Gasparini GP, Ortona A, Budillon G, Astraldi M, Sansone E. The effect of the Eastern Mediterranean Transient on the hydrographic characteristics in the Strait of Sicily and in the Tyrrhenian Sea. Deep Sea Res Part I Oceanogr Res Pap [Internet]. 2005 Jun [cited 2016 Feb 1];52(6):915-35. Available from: http://www.sciencedirect.com/science/article/pii/S096 7063705000348

27. Tanhua, T; Hainbucher, D; Schroeder, G, Cardin, V.; Álvarez MCG. The Mediterranean Sea system: A review and an introduction to the special issue. Ocean Sci. 2013;9(5):789-803.

28. O'Boyle S, McDermott G, Wilkes R. 
Dissolved Oxygen Levels in Estuarine and Coastal Waters Around Ireland. Mar Pollut Bull [Internet]. Elsevier Ltd; 2009;58(11):1657-63. Available from: http://www.ncbi.nlm.nih.gov/pubmed/19665737

29. Ladakis M, Skoullos M, Dassenakis M. Water quality in a mediterranean marine protected area (North Sporades Islands, Greece). Chem Ecol [Internet]. 2003;19(1):47-57. Available from: http://www.tandfonline.com/doi/abs/10.1080/027575 4031000084400

30. Frieder CA, Nam SH, Martz TR, Levin LA. High temporal and spatial variability of dissolved oxygen and $\mathrm{pH}$ in a nearshore California kelp forest. Biogeosciences. 2012;9(10):3917-30.

31. Kunlasak K, Chitmanat C, Whangchai N, Promya J, Lebel L, Al ET. Relationships of Dissolved Oxygen with Chlorophyll-a and Phytoplankton Composition in Tilapia Ponds. Int J Geosc, 2013; 4:46-53.

32. Gilpin LC, Davidson K, Roberts E. The influence of changes in nitrogen: Silicon ratios on diatom growth dynamics. J Sea Res. 2004;51(1):2135 .

33. White DL, Porter DE, Lewitus AJ. Spatial and temporal analyses of water quality and phytoplankton biomass in an urbanized versus a relatively pristine salt marsh estuary. $J$ Exp Mar Bio Ecol. 2004;298(2):255-73.

34. Specchiulli A, Scirocco T, Cilenti L, Florio M, Renzi M, Breber P. Spatial and temporal variations of nutrients and chlorophyll a in a Mediterranean coastal lagoon: Varano lagoon, Italy. Transitional Waters Bull. 2008;2(4):49-62.

35. Penna N, Capellacci S, Ricci F. The influence of the Po River discharge on phytoplankton bloom dynamics along the coastline of Pesaro (Italy) in the Adriatic Sea. Mar Pollut Bull. 2004;48(3-4):321-6.

36. Pettine M, Casentini B, Fazi S, Giovanardi F, Pagnotta R. A revisitation of TRIX for trophic status assessment in the light of the European Water Framework Directive: Application to Italian coastal waters. Mar Pollut Bull. 2007;54(9):1413-26.

37. Vacchi M, Bussotti S, Guidetti P, La Mesa G. Study of the coastal fish assemblage in the marine reserve of the Ustica Island (southern Tyrrhenian Sea). Ital J Zool [Internet]. 1998;65(April):281-6. Available from://000079306600047

38. Buia MC, Mazzella L, Gambi MC, Brandini E, Lorenti M, Procaccini G, et al. Preliminary data on epiphytic flora and vagile fauna of the Posidonia oceanica beds at the marine reserve of Ustica Island (Sicily). XXIX Congr SIBM. 1999;6(January 1999):240-2.

39. Milazzo M, Chemello R, Badalamenti F, Riggio S. Molluscan assemblages associated with photophilic algae in the Marine Reserve of Ustica Island (Lower Tyrrhenian Sea, Italy). Ital J Zool. 2000;67(May 2015):287-95.
40. Milazzo M, Chemello R, Badalamenti F, Riggio S. Short-term effect of human trampling on the upper infralittoral macroalgae of Ustica Island MPA (western Mediterranean, Italy). J Mar Biol Assoc UK. 2002;82(5):745-8.

41. Guidetti P, Milazzo M, Bussotti S, Molinari A, Murenu M, Pais A, et al. Italian marine reserve effectiveness: Does enforcement matter? Biol Conserv. 2008;141(3):699-709.

42. Ape F, Arigò C, Gristina $\mathrm{M}$, Genovese L, Di Franco A, Di Lorenzo M, et al. Meiofaunal Diversityand Nematode Assemblages in Two Submarine Caves of a Mediterranean Marine Protected Area. Mediterr Mar Sci [Internet]. 2015;17(1). Available from: http://www.medit-marsc.net/index.php/marine/article/view/1375 